\title{
Autoimmunity and Antibody Dependent COVID-19 Enhancement of SARS CoV-2 Vaccination: A Global Human Right to Know then Decide.
}

\author{
Mina Kelleni ${ }^{1}$ \\ ${ }^{1}$ Affiliation not available
}

August 2, 2021

\begin{abstract}
Nucleic acid based - mRNA based and adenovirus vectored - vaccines, were first ever or first commercially ever approved for the public, respectively. However, these newly emergency approved types possess a potential risk to induce auto-immune diseases e.g., thrombocytopenia, myocarditis and immune induced thrombosis and thromboembolism that might be fatal and could reason for some of the post vaccination sudden death reports. Moreover, all SARS CoV-2 types of vaccines, depending on the spike protein immunogenicity, especially the conventional inactivated ones might increase the likelihood of COVID-19 severity upon re-infection through antibody dependent enhancement which might reason for the recently described abundance of hospital admissions within seven days of vaccination and might also reason for some of the serious adverse effects encountered with administration of convalescent plasma to COVID-19 patients as well as they might share in development of some lethal SARS CoV-2 variants. Importantly, we suggest that SARS CoV-2 mass vaccination campaigns were the worst ever decision made and that making these COVID-19 vaccines compulsory or administering them to children or pregnant participants might be considered as a crime against humanity to the extent that no prior companies- governmental agreements would ever secure impunity. Finally, a full informed personalized risk benefit ratio especially for some described high-risk groups must be secured while suggesting that the subunit vaccines are the least hazardous ones.
\end{abstract}

\section{Hosted file}

SARS CoV-2 Vaccines Complications6.pdf available at https://authorea.com/users/318758/ articles/522091-autoimmunity-and-antibody-dependent-covid-19-enhancement-of-sars-cov2-vaccination-a-global-human-right-to-know-then-decide

\section{Hosted file}

SARS CoV-2 Vaccines Complications5.pdf available at https://authorea.com/users/318758/ articles/522091-autoimmunity-and-antibody-dependent-covid-19-enhancement-of-sars-cov2-vaccination-a-global-human-right-to-know-then-decide

\section{Hosted file}

SARS CoV-2 Vaccines Complications4.pdf available at https://authorea.com/users/318758/ articles/522091-autoimmunity-and-antibody-dependent-covid-19-enhancement-of-sars-cov2-vaccination-a-global-human-right-to-know-then-decide

\section{Hosted file}

SARS CoV-2 Vaccines Complications3.pdf available at https://authorea.com/users/318758/ articles/522091-autoimmunity-and-antibody-dependent-covid-19-enhancement-of-sars-cov2-vaccination-a-global-human-right-to-know-then-decide 


\section{Hosted file}

SARS CoV-2 Vaccines Complications2.pdf available at https://authorea.com/users/318758/ articles/522091-autoimmunity-and-antibody-dependent-covid-19-enhancement-of-sars-cov2-vaccination-a-global-human-right-to-know-then-decide

\section{Hosted file}

SARS CoV-2 Vaccines Complications1.pdf available at https://authorea.com/users/318758/ articles/522091-autoimmunity-and-antibody-dependent-covid-19-enhancement-of-sars-cov2-vaccination-a-global-human-right-to-know-then-decide

\section{Hosted file}

SARS CoV-2 Vaccines Complications.pdf available at https://authorea.com/users/318758/ articles/522091-autoimmunity-and-antibody-dependent-covid-19-enhancement-of-sars-cov2-vaccination-a-global-human-right-to-know-then-decide 